\title{
Penjualan Harta Waris Berupa Tanah Tanpa Adanya Persetujuan Ahli Waris Lainnya
}

\author{
Ni Made Eka Yanti Purnawan \\ Program Studi Magister (S2) Kenotariatan, Fakultas Hukum Udayana, \\ E-mail: kadekpurnawan16@gmail.com
}

\begin{tabular}{l}
\hline Info Artikel \\
\hline Masuk: 24 Juli 2020 \\
Diterima: 29 Juli 2020 \\
Terbit: 31 Juli 2020 \\
Keywords: \\
Inherited Land; Inherited Land \\
Sales; Approval; Heirs \\
\\
\\
Kata kunci: \\
Tanah Warisan; Penjualan \\
Tanah warisan; Persetujuan; \\
Ahli Waris. \\
Corresponding Author: \\
Ni Made Eka Yanti Purnawan, \\
E-mail: \\
kadekpurnawan16@gmail.com \\
DOI: \\
10.24843/AC.2020.v05.i02.p09 \\
\end{tabular}

\section{Pendahuluan}

Dalam ruang lingkup agraria, tanah merupakan bagian dari bumi, yang disebut permukaan bumi. Tanah yang dimaksud di sini bukan mengatur tanah dalam segala aspeknya, melainkan hanya mengatur salah satu aspeknya, yaitu tanah dalam pengertian yuridis yang disebut hak. Objek Hukum Tanah dibagi menjadi Hak Penguasaan atas tanah sebagai lembaga hukum dan Hak penguasaan atas tanah sebagai hubungan hukum yang konkret. Dalam kaitannya dengan hubungan hukum antara pemegang hak dengan hak atas tanahnya, ada dua macam asas dalam hubungan hukum antara orang dengan tanah yaitu Asas Accesie atau asas pelekatan, dalam hal ini bangunan dan tanaman yang ada di atas tanah merupakan satu kesatuan, bangunan dan tanaman tersebut bagian dari tanah yang bersangkutan. Hak

\begin{abstract} existence of land is a place for all people to live their lives. Regarding inherited land, there are often disputes between heirs. The purpose of this study is to examine the sale of inherited land without the consent of other heirs. This study uses a normative No. 5 of 1960 and Government Regulation No. 37 of 1998 . The results of the study indicate that the sale of inherited land by an heir must obtain the approval of the other heirs. With the approval, it is unlikely that there will be a gap for other heirs to challenge or object to the Land Purchase.
\end{abstract}


atas tanah dengan sendirinya, karena hukum meliputi juga pemilikan bangunan dan tanaman yang ada diatas tanah yang dihaki, kecuali kalau ada kesepakatan lain dengan pihak yang membangun atau menanamnya. Kedua asas Horizontale Scheiding atau asas pemisahan horizontal, dalam asas ini bangunan dan tanaman yang ada diatas tanah bukan merupakan bagian dari tanah. Hak atas tanah tidak dengan sendirinya meliputi pemilikan bangunan atau tanaman yang ada diatasnya. Perbuatan hukum mengenai tanah tidak dengan sendirinya meliputi bangunan atau tanaman milik yang punya tanah yang ada diatasnya. Jika perbuatan hukumnya dimaksudkan meliputi juga bangunan dan tanamannya, maka hal ini secara tegas harus dinyatakan perbuatan hukum yang bersangkutan.

Sengketa mengenai kepemilikan tanah dapat timbul dikarenakan salah satu ahli waris menguasai tanah waris seluruhnya sehingga ada ahli waris lain yang dirugikan selain itu jual beli yang dilakukannya tersebut tanpa persetujuan dari ahli waris lainnya. Sengeta hak atas tanah dapat terjadi karena adanya gugatan dari seseorang atau badan hukum akibat perbuatan hukum yang telah merugikan hak penggugat atas tanah. Adapun materi gugatan dapat berupa tuntutan akan adanya kepastian hukum mengenai siapa yang berhak atas tanah, bukti-bukti yang menjadi dasar pemberian hak. Selain itu dapat terjadi akibat perjanjian jual beli, sewa-menyewa, atau pewarisan. Dalam hal pembagian harta waris, permasalahan yang terjadi seputar perebutan harta warisan, seperti masing-masing ahli waris merasa tidak adanya pembagian harta waris yang adil antar ahli waris serta tidak adanya kesepakatan menengenai hukum yang akan mereka gunakan apabila terjadi sengketa atau permasalahan di kemudian hari. Sehingga dalam melakukan pembagian harta warisan harus didasarkan pada kesepakatan dari pewaris maupun ahli waris, salah satu bentuknya adalah dengan cara melakukan pembagian harta warisan dengan jumlah yang sama tanpa memerhatikan status penerima warisan apakah laki-laki atau perempuan selain itu dalam melakukan pembagian warisan lebih baik diketahui oleh seluruh ahli waris yang sah maka hal tersebut akan meminimalisirkan terjadinya sengketa dikemudian hari. ${ }^{1}$

Hal tersebut merupakan salah satu dari banyaknya permasalah harta waris yang masuk ke pengadilan. Mengingat banyaknya kasus semacam ini, maka dalam studi ini menjadi penting dikaji tentang keabsahan penjualan tanah waris oleh salah satu ahli waris tanpa persetujuan dari ahli waris lainnyai dalam perspektif hukum perdata.

\section{Metode Penelitian}

Metode penelitian merupakan hal penting dalam penulisan atau penyusunan karya tulis ilmiah agar pengkajian dan penganalisaan terhadap objek penelitian dapat dilakukan dengan benar dan optimal. Tipe penelitian yang digunakan dalam penelitian ini mengunakan yuridis normatif yang berarti penelitian ini difokuskan untuk mengkaji penerapan-penerapan, kaidah-kaidah, atau norma-norma dalam hukum positif yang berlaku. Metode pendekatan masalah yang digunakan dalam penelitian ini adalah Pendekatan perundang-undangan (Statute Approach). Pendekatan perundang-undangan (Statue Approach) yaitu menelaah semua Undang-Undang yang

\footnotetext{
${ }^{1}$ Anita Kamilah (2015). Kajian Terhadap Penyelesaian Sengketa Pembagian Harta Warisan Atas Tanah Akibat Tidak Dilaksanakannya Wasiat Oleh AhliWaris Dihubungkan Dengan Buku II Kitab UndangUndang Hukum Perdata tentang Benda (Van Zaken). Jurnal Fakutas Hukum Universitas Suryakancana Cianjur. http://dx.doi.org/10.25072/jwy.v32i1.87
} 
berkaitan dengan isu hukum yang sedang ditangani. ${ }^{2}$ Adapun udang-undang yang menjadi acuan dalam penulisan penelitian ini adalah bersumber pada UndangUndang Hukum Perdata. Sedangkan Bahan hukum yang digunakan dalam penulisan penelitian ini menggunakan bahan hukum primer, bahan hukum sekunder dan bahan hukum tertier.

\section{Hasil Dan Pembahasan}

Pada prinsipnya, ketika seseorang meninggal dunia maka seluruh harta kekayaannya akan jatuh kepada ahli warisnya, karena secara hukum para ahli waris ini terbagi menjadi beberapa golongan, ${ }^{3}$ maka ketika membeli tanah warisan harus dipastikan langsung berhadapan dengan ahli waris yang sah. Apabila ahli waris lebih dari satu orang maka sebaiknya bertransaksi dengan seluruh ahli warisnya agar tidak terjadi sengketa dikemudian hari. Jika salah satu atau lebih ahli waris tidak dapat hadir maka dapat diwakili oleh orang lain dengan syarat adanya pemberian kuasa. Pemberian kuasa tersebut harus dilakukan dengan menggunakan akta notaris. Bahkan jika diperlukan dalam transaksi jual beli tanah warisan seluruh ahli waris dapat memberikan kuasanya kepada salah satu ahli waris saja untuk menandatangani Akta Jual Beli tersebut. ${ }^{4}$ Hal paling penting lainnya dalam membeli tanah warisan yaitu memeriksa dan memastian keabsahan dari para pewaris dan ahli warisnya. Untuk memastikan bahwa tanah tersebut adalah benar tanah warisan dari pemiliknya yang telah meninggal dunia, maka diperlukannya surat keterangan kematian, surat keterangan kematian tersebut yang membuktikan bahwa orang yang namanya tertera disertifikat tanah memang benar telah meninggal dunia, ${ }^{5}$ sedangkan untuk membuktikan bahwa yang bersangkutan merupakan ahli warisnya yang sah, penting memeriksa surat keterangan ahli waris, surat tersebut menjelaskan siapa-siapa saja yang ditunjuk untuk menjadi ahli waris dari orang yang meninggal tersebut.

Sengketa perdata atas tanah juga dapat terjadi akibat adanya perjanjian pengalihan hak atas tanah, seperti perjanjian jual beli, sewa menyewa atau pewarisan. Pewarisan berkaitan dengan apabila salah satu suami atau istri meninggal dunia, maka sesuai dengan hukum waris harus sudah diperhitungkan pembagian dari jumlah harta warisannya (legietieme portie) ${ }^{6}$ khususnya berkaitan dengan harta berupa benda tidak bergerak dalam hal ini tanah walaupun dalam kenyataannya tidak pernah ada perjanjian bagi waris dan nama yang tertera atas nama suami atau istri tersebut namun hal itu tentu saja tidak menjadikan harta tersebut ekslusif dapat menjadi hak sepenuhnya atas nama harta benda tidak bergerak itu, karena dalam hal ini jumlah bagian anak sah dan suami atau istri yang ditinggalkan harus telah diperhitungkan pembagiannya. Harta Warisan apabila telah dibagi ke masing-masing ahli waris, dan sudah tidak ada bagian yang disengketakan maka otmati statusnya telah berpindah

2 Peter Mahmud Marzuki, Penelitian Hukum, Kencana, Jakarta, 2005. hlm. 96.

3 Irma Devita Purnamasari, Kiat-Kiat Cerdas, Mudah, dan Bijak Memahami Masalah Hukum Waris, PT Mizan Pustaka, Bandung, Januari 2014, hlm. 3.

${ }^{4}$ Ibid.

${ }^{5}$ Ibid., hlm. 176.

${ }^{6}$ Legitieme Portie atau bagian warisan menurut undang-undang ialah bagian dan harta benda yang harus diberikan kepada ahli waris dalam garis lurus menurut unda ng-undang, yang terhadapnya orang yang meninggal dunia tidak boleh menetapkan sesuatu, baik sebagai hibah antara orang-orang yang masih hidup, maupun sebagai wasiat (Pasal $913 \mathrm{Kitab}$ Undang-Undang Hukum Perdata). 
tangan ke ahli waris, sehingga menjadi hak milik ahli waris. ${ }^{7}$ Setelah menjadi miliknya, ahli waris berhak untuk menggunakan harta itu. Boleh dijual, boleh juga dihibahkan, atau disedekahkan, atau untuk aktivitas lainnya.

Sebagian besar tanah waris merupakan harta bersama. Apabila tanah waris itu akan dijual, maka seluruh ahli waris harus hadir dan memberikan persetujuan. ${ }^{8}$ Dalam hal salah seorang ahli waris tidak dapat dapat hadir untuk memberikan persetujuan dihadapan notaris pembuat akta tanah tersebut, maka ahli waris tersebut dapat membuat Surat Persetujuan dibawah tangan yang dilegalisasi notaris setempat atau membuat Surat Persetujuan dalam bentuk Akta Notaris. Pada jual beli tanah sebaiknya dilakukan oleh para pihak dihadapan pejabat pembuat akta tanah (PPAT), karena untuk menjamin kepastian hukum kepemilikan tanah tersebut. Adapun akta PPAT memiliki fungsi sebagai alat pembuktian mengenai benar telah dilakukannya jual beli tersebut. Seseorang yang melakukan jual beli tanpa dapat dibuktikan dengan adanya akta PPAT tidak akan dapat memperoleh sertifikat, walaupun nantinya jual. ${ }^{9}$

Dalam hal jual beli tanah yang dilaukan tidak ada persetujuan dari para ahli waris yang lainnya, dan tanah tersebut dijual oleh orang yang tidak berhak untuk menjualnya berdasarkan Pasal 1471 Kitab Undang-Undang Hukum Perdata, 10 jual beli tersebut batal. Dengan batalnya jual beli tersebut, maka jual beli tersebut dianggap tidak pernah ada, dan masing-masing pihak dikembalikan ke keadaannya semula sebelum terjadi peristiwa "jual beli" tersebut, yang mana hak milik atas tanah tetap berada pada ahli waris. Selain itu, jual beli tanpa menyertakan sertifikat tanah juga bertentangan dengan persyaratan dalam proses jual beli tanah.

Seluruh ahli waris berhak atas tanah warisan yang diwariskan oleh pewaris. Jjika salah satu pihak ahli waris ingin melakukan jual beli tanah, tidaklah cukup hanya dihadiri oleh pemilik yang tercantum dalam Bukti Kepemilikan Tanah yang menandatangani Akta Jual Beli atas tanah tersebut namun, penjualan tersebut harus melibatkan seluruh ahli waris yang tercantum. Jika tidak dihadiri oleh seluruh ahli waris yang telah ditunjuk atau keluarga pemilik tanah yang merasa tidak pernah menjual tanah tersebut dapat mengajukan gugatan. ${ }^{11}$ Selain konstruksi hukum waris, ada pula Hibah berkaitan dengan tanah. Hibah merupakan perjanjian sepihak yang dilakukan dengan cuma-Cuma. Artinya, tidak adanya kontra prestasi dari pihak penerima hibah. ${ }^{12}$ Yang menjadi objek perjanjian hibah adalah segala macam harta benda milik pengibah, baik benda berwujud maupun yang tidak berwujud, benda tetap maupun benda bergerak, termasuk juga segala macam piutang penghibah. ${ }^{13}$ Menurut Pasal 1666 Kitab UndangUndang Hukum Perdata, hibah dirumuskan sebagai berikut: "Hibah adalah suatu perjanjian dengan mana si penghibah, pada waktu hidupnya, dengan cuma-cuma dan dengan tidak dapat ditarik kembali, menyerahkan sesuatu benda guna keperluan si penerima hibah yang menerima penyerahan itu."

\footnotetext{
7 Irma Devita Purnamasari, op. cit., hlm. 176.

8 Ibid.

${ }^{9}$ Ferri Adi Purwantono, (2018), Tinjauan Yuridis Implikasi Perjanjian Jual-Beli Dalam Keluarga Yang Dibuat Oleh NotarisTerhadap Kedudukan Ahli Waris, Jurnal Magister (S2) Kenotariatan Fakultas Hukum UNISSULA.

10 Jika ada saat penjualan, barang yang dijual telah musnah sama sekali, maka pembelian adalah batal (Pasal 1471 Kitab Undang-Undang Hukum Perdata)

${ }^{11}$ Ibid., hlm. 182

12 Eman Suparman, Hukum Waris Indonesia, PT. Refika Aditama, Bandung, 2005. Hlm. 86.

${ }^{13}$ Ibid.
} 
Tanah warisan yang akan diperjualbelikan memiliki konsekuensi dengan para ahli warisnya yakni setiap ahli waris berhak atas kepemilikan tanah tersebut. Maka ketika ada seorang ahli waris menjual tanah warisan tersebut pada mulanya telah terjadi kesepakatan antara pihak penjual tanah warisan tersebut dengan pihak pembelinya. Namun, setelah tanah yang disepakati tersebut dijual dan dibayar oleh pembeli secara sah dihadapan para saksi, ada ahli waris lain yang juga berhak atas kepemilikan tanah warisan tersebut mempersengketakan lantaran merasa dirinya tidak diikutkan dalam kegiatan jual beli tanah tersebut. Dengan kata lain, bahwa ahli waris dari tanah warisan tersebut tidak menyetujui atau menolak untuk adanya peralihan hak atas tanah untuk dimiliki orang lain. Sehingga, terjadilah sengketa atas jual beli tanah tersebut yang disebut sebagai Asas "hereditatis petition" yaitu hak dari ahli waris untuk menuntut yang termasuk dalam harta peninggalan dari si pewaris terhadap orang yang yang menguasai harta warisan tersebut untuk diserahkan padanya berdasarkan haknya sebagai ahli waris. Asas ini diatur dalam pasal 834 Kitab Undang-Undang Hukum Perdata.

Jual beli merupakan suatu perjanjian antara pihak yang satu (penjual) mengikatkan dirinya untuk menyerahkan hak milik atas suatu benda dari pihak yang lain (pembeli) untuk membayar harga yang telah diperjanjikan (Pasal 1457 Kitab Undang-Undang Hukum Perdata). Dalam pasal 1455 Kitab Undang-Undang Hukum Perdata ${ }^{14}$ menyebutkan bahwa jual beli itu dianggap telah terjadi antara kedua belah pihak pada saat mereka mencapai kata sepakat mengenai benda yang diperjualbelikan itu serta harganya, biarpun benda tersebut belum diserahkan dan harganya pun belum dibayar. Namun, Tanah yang dijual akan mendapat masalah, apabila dihadapakan pada persoalan tanah warisan seperti tersebut diatas. Tanah warisan merupakan bagian dari harta peninggalan berupa benda tidak bergerak milik pewaris yang akan diwariskan kepada para ahli waris. Sedangkan ahli waris merupakan orang yang memiliki hak atas harta peninggalan pewaris, dalam hal ini berupa tanah. Pada dasarnya setiap ahli waris dapat mencegah teradinya penjualan apabila diantara mereka terjadi ketidaksepakatan atas tanah yang akan dijual berakibat kepada tindakan kepemilikan atas tanah tersebut.

Seorang ahli waris harus meminta persetujuan dari ahli waris yang lainnya apabila dirinya hendak menjual tanah warisannya, sebab ahli waris yang lainnya juga memiliki hak atas tanah tersebut. ${ }^{15}$ Apabila seseorang yang berhak atas tanah warisan menyatakan sebagai bahwa ahli waris satu-satunya, maka pembelian tersebut tidak boleh dianggap diadakan berdasarkan persyaratan-persyaratan secara diam-diam. Jika ahli waris lainnya yang juga berhak atas tanah tersebut tidak dilibatkan, dalam arti tidak ada persetujuannya, maka terjadilah sengketa atas jual beli tanah tersebut. Setiap orang selalu ingin mempertahankan hak-haknya, begitu pula ahli waris terhadap tanah yang diwariskannya. Sengketa yang demikian tidak dapat diabaikan tanpa ditangani secara sungguh-sungguh, oleh karena itu apabila hal tersebut dibiarkan, maka akan menimbulkan hal-hal yang tidak diinginkan. Timbulnya sengketa bermula dari pengaduan ahli waris yang berisi keberatan-keberatan dan tuntutan hak atas tanah warisan, baik terhadap status tanah, prioritas maupun kepemilikannya dengan harapan dapat memperoleh penyelesaian secara administrasi sesuai dengan ketentuan yang berlaku. Sebenarnya usaha-usaha untuk menghindari terjadinya sengketa hak atas tanah warisan yang diperjualbelikan oleh sebagian ahli waris dapat dilakukan

${ }^{14}$ Kitab Undang-Undang Hukum Perdata.

${ }^{15}$ Irma Devita Purnamasari, op. cit., Hlm. 176. 
secara preventif pada saat pemberian hak diproses, yaitu dengan jalan musyawarah diantara para ahli waris. Tindakan yang bersifat pencegahan ini sebenarnya lebih efektif dibandingkan dengan usaha penyelesaian sengketa apabila masalah tersebut telah bergulir di pengadilan sebaai tindakan yang disebut respresif.

Dalam hal ini, perbuatan ahli waris yang menjual tanah tanpa persetujuan ahli waris yang lainnya merupakan perbuatan yang melanggar hak subjektif para ahli waris lainnya. Namun untuk dapat menggugat penjual tanah tersebut atas dasar perbuatan melawan hukum, terlebih dahulu harus dapat membuktikan bahwa orang yang akan digugat memenuhi semua unsur-unsur perbuatan melawan hukum sebagaimana seperti yang disebutkan di atas. Hal ini didukung juga dengan adanya Pasal $834 \mathrm{Kitab}$ Undang-Undang Hukum Perdata ${ }^{16}$, yang memberikan hak kepada ahli waris untuk mengajukan gugatan guna memperjuangkan hak warisnya terhadap orang-orang yang menguasai seluruh atau sebagian harta peninggalan, baik orang tersebut menguasai atas dasar hak yang sama atau tanpa dasar sesuatu hak pun atas harta peniggalan tersebut.

Mengenai apakah dapat menarik kembali hak milik atas tanah yang telah dijual, hal itu bergantung pada apa yang minta dalam petitum gugatan dan bergantung pada putusan hakim. Pasal 834 Kitab Undang-Undang Hukum Perdata telah memberikan para ahli waris dasar untuk meminta kembali tanah warisan tersebut. Para ahli waris dapat mengajukan gugatan untuk meminta agar diserahkan kepadanya segala haknya atas harta peninggalan beserta segala hasil, pendapatan, dan anti rugi yang telah dilakukan.

Status tanah warisan yang dijual adalah sebagai akibat dari telah dilakukannya proses jual beli akan menjadi hal yang sangat rumit apabila tidak berdasarkan atas kesepakatan maupun persetujuan para ahli waris yang lainnya. Namun tanah yang menjadi persengketaan dapat diselesaikan melalui kekeluargaan. ${ }^{17}$ Akan tetapi apabila tidak bisa diselesaikan lewat musyawarah kekeluargaan, maka cara yang dapat ditempuh selanjutnya melalui jalur pengadilan yang akan menyelesaikannya, dengan tujuan mencari keadilan. Penyelesaian sengketa atas tanah warisan senantiasa harus memperhatikan dan mendasarkan kepada peraturan-peraturan yang berlaku, serta memperhatikan keseimbangan kepentingan-kepentingan para pihak selain itu harus diselesaikan dengan adil dan tuntas. ${ }^{18}$

Sengketa tanah terjadi dikarena tanah mempunyai peranan yang penting, dalam membuktikan kepemilikan atas suatu benda. Tanah mempunyai fungsi dalam rangka integritas negara dan fungsi sebagai modal dasar dalam rangkan mewujudkan sebesarbesarnya kemakmuran rakyat. Pentingnya kedudukan tanah bagi negara Republik Indonesia dapat dilihat dalam ketentuan Pasal 1 Undang-Undang Pokok Agraria ${ }^{19}$ yang menyebutkan: Seluruh wilayah Indonesia adalah kesatuan tanah air dari seluruh rakyat Indonesia yang bersatu sebagai bangsa Indonesia.

1. Seluruh bumi, air, dan ruang angkasa termasuk kekayaan alam yang terkandung didalamnya dalam wilayah Republik Indonesia sebagai karunia Tuhan Yang Maha Esa adalah bumi, air dan ruang angkasa bangsa Indonesia dan merupakan kekayaan nasional.

\footnotetext{
16 Ibid.

17 Elza Syarief, op. cit., Hlm. 208.

18 Ibid.

${ }^{19}$ Lihat Pasal 1 Undang-Undang Agraria No. 5 Tahun 1960.
} 
2. Hubungan antara bangsa Indonesia dan bumi, air serta ruang angkasa termasuk dalam ayat (2) Pasal ini adalah hubungan yang bersifat abadi.

3. Dalam pengertian bumi selain permukaan bumi, termasuk pula tanah bumi dibawahnya serta berada dibawah air.

4. Dalam pengertian air termasuk baik perairan pedalaman maupun wilayah Indonesia.

5. Yang dimaksud ruang angkasa ialah ruang diatas bumi dan air tersebut ayat (4) dan ayat (3) pasal ini.

Berdasarkan ketentuan tersebut dijelaskan bahwa bagi bangsa Indonesia, tanah memiliki hubungan yang sangat erat dan bersifat abadi, sehingga kedudukan tanah bagi bangsa Indonesia merupakan satu kesatuan utuh yang tidak dapat dipisahkan satu sama lainnya. Ketentuan ini bersifat imperatif, karena mengandung perintah kepada Negara agar bumi, air, dan kekayaan alam yang terkandung didalamnya, yang diletakan dalam penguasaan Negara itu dipergunakan untuk mewujudkan kemakmuran bagi seluruh rakyat Indonesia.

Dalam jual beli tanah warisan apabila tanah tersebut akan dijual, maka seluruh ahli waris yang telah ditunjuk secara sah harus hadir untuk memberikan persetujuan terkait penjualan tanah yang akan dilakukan. Dalam hal salah seorang ahli waris tidak bisa hadir di hadapan Notaris pembuat akta tersebut (karena berhalanan hadir), maka ahli waris tersebut dapat membuat Surat Persetujuan di bawah tangan yang dilegalisir notaris setempat atau dibuat Surat persetujuan dalam bentuk akta notaris. ${ }^{20}$ Sedangkan Dalam hal jual beli tanah tersebut tidak ada persetujuan dari para ahli waris, maka tanah tersebut dijual oleh orang yang tidak berhak untuk menjualnya (karena yang sekarang memegang hak milik atas tanah tersebut yaitu para ahli waris). Oleh karena itu, berdasarkan Pasal 1471 Kitab Undang-Undang Hukum Perdata, ${ }^{21}$ jual beli tersebut batal. Dengan batalnya kegiatan jual beli tersebut, maka jual beli tersebut dianggap telah batal atau tidak pernah ada, dan masing-masing pihak dikembalikan ke keadaannya semula sebelum terjadi peristiwa "jual beli" tersebut, yang mana hak milik atas tanah tetap berada pada seluruh ahli waris yang telah ditentukan. ${ }^{22}$ Penyelesaian sengketa tanah dapat diajukan dengan mengajukan gugatan keperdataan. Misalnya sengketa mengenai hak waris. Jual beli tanah yang berdimensi keperdataan dalam kasus ini. Prosedur yang dilakukan pertama kali adalah mengajukan gugatan. Gugatan harus diajukan surat gugat yang ditandatangani oleh penggugat atau kuasanya yang sah dan ditujukan kepada Ketua Pengadilan Negeri. Gugatan disampaikan kepada pengadilan negeri, selanjutnya diberi nomor dan didaftarkan dalam buku register setelah penggugat membayar biaya perkara yang besarnya ditentukan oleh pengadilan negeri. Bagi penggugat yang benar-benar tidak mampu membayar biaya perkara, hal yang harus dibuktikan dengan surat keterangan dari kepala desa yang bersangkutan, dapat mengajukan gugatannya secara prodeo. Bagi Penggugat yang tidak bisa menulis dapat mengajukan gugatannya secara lisan dihadapan Ketua Pengadilan Negeri, yang akan menyuruh mencatat gugatan tersebut.

${ }^{20}$ Irma Devita Purnamasari, op. cit., hlm. 177

${ }^{21}$ Jual beli atas barang orang lain adalah batal dan dapat memberikan dasar kepada pembeli untuk menuntut penggantian biaya, kerugian dan bunga, jika ia tidak mengetahui bahwa barang itu kepunyaan orang ain. (Pasal 1471 Kitab Undang-Undang Hukum Perdata)

22 Sabungan Sibarani (2015). Penerapan Legitime Portie (Bagian Mutlak) dalam pembagian Waris Menurut Kitab Undang-Undang Hukum Perdata (Studi Kasus Putusan Nomor 320/PDT/G/PN.JKT.BAR). Jurnal Fakutas Hukum Universitas Borobudur. http://ejurnal/jphukumdd151659 
Sehingga pembuktian dalam hukum acara perdata merupakan suatu hal yang sangat penting, karena menentukan kebenaran itulah dicari bukti-bukti yang turut memberikan penerangan bagi hakim dalam mengambil putusan akhir.

Putusan hakim atau yang disebut dengan istilah putusan pengadilan merupakan sesuatu yang sangat diharapkan oleh para pihak yang berperkara dipengadilan guna dapat menyelesaikan sengketa yang dihadapi, dengan putusan hakim yang seadiladilnya. Dengan demikian dapat disimpulkan bahwa, suatu putusan hakim merupakan surat pernyataan yang dibuat secara tertulis oleh hakim sebagai pejabat Negara yang diberi wewenang untuk itu yang diucapkan dimuka persidangan sesuai dengan perundangan yang berlaku yang menjadi hukum bagi para pihak yang mengandung perintah kepada suatu pihak supaya melakukan suatu perbuatan atau melakukan suatu perbuatan yang harus ditaati.

Putusan Pengadilan merupakan suatu yang sangat diinginkan atau dinanti-nanti oleh pihak-pihak yang berperkara untuk menyelesaikan sengketa mereka dengan sebaikbaiknya. Sebab dengan putusan Pengadilan tersebut pihak-pihak yang bersengketa mengharapkan adanya kepastian hukum-hukum keadilan dalam perkara yang mereka hadapi. Untuk memberikan putusan Pengadilan yang benar-benar menciptakan kepastian dan mencerminkan keadilan Hakim sebagai aparatur negara dan sebagai wakil Tuhan yang melaksanakan peradilan harus mengetahui duduk perkara yang sebenarnya dan peraturan hukum yang akan ditetapkan baik peraturan hukum tertulis dalam perundang-undangan maupun peraturan hukum tidak tertulis atau hukum adat. Putusan Hakim menurut I Rubini dan Chidir Ali, merumuskan bahwa:

"Keputusan Hakim merupakan suatu akta penutup dari proses perkara dan putusan hakim itu disebut Vonnis yang menurut kesimpulan-kesimpulan terakhir mengenai hukum dari Hakim serta memuat pula akibat-akibatnya"

Pentingnya penyelesaian suatu sengketa diharapkan dapat memperoleh jaminan adanya kepastian hukum bagi seluruh pihak yang terlibat dalam suatu persengketaan. Tujuan kepastian hukum itu sendiri dapat terpenuhi apabila seluruh perangkat atau sistem hukum itu berjalan dan mendukung tercapainya suatu kepastian hukum, khususnya peranan lembaga-lembaga yang diberi wewenang khusus untuk menyelesaikannya. ${ }^{23}$ Dalam sistem hukum Indonesia, penyelesaian sengketa, khususnya pertanahan, dapat dilakukan melalui berbagai proses penyelesaian, baik melalui lembaga peradilan seperti dalam peradilan umum, peradilan tata usaha negara, maupun penyelesaian sengketa diluar lembaga peradilan seperti penyelesaian melalui mediasi, arbitrase maupun penyelesaian lembaga adat, dan sebagainya. Banyaknya lembaga yang memiliki wewenang dalam penyelesaian sengketa pertanahan sering menimbulkan tumpang tindih kebijakan atau keputusan yang bersifat kelembagaan, merupakan salah satu faktor penyebab kurang terjaminnya kepastian hukum dalam penyelesaian sengketa pertanahan di Indonesia. Dalam praktik yang berlaku sekarang, proses beracara dipersidangan dalam perkara perdata terkait sengketa tanah pada hakikatnya tidak berbeda dengan sengketa perdata lainnya, yaitu mengacu pada hukum acara perdata yang berlaku pada saat ini. ${ }^{24}$ Proses hukum penyelesaian sengketa yang dimulai dari tingkat pertama sampai mempunyai kekuatan hukum tetap biasanya memerlukan waktu yang sangat panjang. Dalam memutus perkara yang terpenting adalah kesimpulan hukum atas fakta yang terungkap dipersidangan. Untuk itu hakim harus menggali nilai-nilai, mengikuti, dan

${ }^{23}$ Elza Syarief, op. cit., hlm. 372.

${ }^{24} \mathrm{Ibid}$. 
memahami nilai-nilai hukum dan rasa keadilan yang hidup dalam masyarakat. Sumber hukum yang dapat diterapkan oleh hakim dapat berupa peraturan perundang-undangan berikut peraturan pelaksanaannya, hukum tidak tertulis (hukum adat), putusan desa, yurisprudensi, ilmu pengetahuan maupun doktrin/ajaran para ahli.

\section{Kesimpulan}

Tanah warisan yang hendak diperjualbelikan tentu saja memiliki hubungan yang sangat penting dengan para ahli warisnya yakni bahwa setiap ahli waris berhak atas kepemilikan tanah tersebut. Maka ketika seorang orang ahli waris ingin menjual tanah warisan tersebut pada mulanya telah terjadi kesepakatan antara pihak penjual tanah warisan tersebut dengan pihak pembelinya maka seluruh ahli waris yang lainnya yang tertera sebagai ahli waris yang sah harus hadir untuk memberikan persetujuan. Apabila jual beli tanah tersebut tidak ada persetujuan dari seluruh para ahli waris, maka perjanjian jual beli tanah tersebut batal demi hukum.

\section{$\underline{\text { Daftar Pustaka }}$}

Marzuki, P.M. (2005). Penelitian Hukum, Jakarta: Kencana.

Purnamasari, I.D. (2014). Kiat-Kiat Cerdas, Mudah, dan Bijak Memahami Masalah Hukum Waris, Bandung: PT Mizan Pustaka.

Syarief, E. (2014). Menuntaskan Sengketa Tanah Melalui Pengadilan Khusus Pertanahan, Jakarta: PT. Gramedia.

Abdurahman. (2004). Kedudukan Hukum ADAT dalam Perundang-undangan Agraria Indonesia, Jakarta: Akademik Presindo.

Samudera, T. (2014). Hukum Pembuktian dalam Acara Perdata, Bandung: PT. Alumni.

\section{JURNAL}

Anita Kamilah (2015). Kajian Terhadap Penyelesaian Sengketa Pembagian Harta Warisan Atas Tanah Akibat Tidak Dilaksanakannya Wasiat Oleh Ahli Waris Dihubungkan Dengan Buku II Kitab Undang-Undang Hukum Perdata tentang Benda (Van Zaken). Jurnal Fakutas Hukum Universitas Suryakancana Cianjur. http://dx.doi.org/10.25072/jwy.v32i1.87

Ferri Adi Purwantono (2018). Tinjauan Yuridis Implikasi Perjanjian Jual-Beli Dalam Keluarga Yang Dibuat Oleh NotarisTerhadap Kedudukan Ahli Waris. Jurnal Magister (S2) Kenotariatan Fakultas Hukum UNISSULA.

Rochmad (2017). Pembagian Harta Waris Antara Anak Laki-Laki Dan Anak Perempuan: Studi Putusan Pengadilan Agama Semarang Nomor: 1545/PDT.G/2010/PA.SM. Jurnal Hukum Khaira Ummah Vol. 12. No. 4 Desember 2017.

SidikTon dan M. Roem Syibly (2014). Wasiat Sebaai Alternatif Masalah dan Pembagian Harta Peninggalan. Jurnal Hukum FAI Universitas Islam Indonesia. http://ejurnal/jphukumdd141197.

Islamiyati (2015). Analisis Asas Keadilan pada Pembagian Harta Waris Menurut Hukum Islam. Jurnal Universitas Diponegoro Semarang. http://e-jurnal/ jphukumdd151078

Imaniar Puti Novianti (2016). Kedudukan dan Kewenangan Balai Harta Peninggalan dalam 
Pengelolaan Harta Peninggalan Tak Teururus. Jurnal Universitas Negeri Semarang. http://e-jurnal/ jphukumdd150297

Sabungan Sibarani (2015). Penerapan Legitime Portie (Bagian Mutlak) dalam pembagian Waris Menurut Kitab Undang-Undang Hukum Perdata (Studi Kasus Putusan Nomor 320/PDT/G/PN.JKT.BAR). Jurnal Fakutas Hukum Universitas Borobudur. http://e-jurnal/jphukumdd151659

\section{UNDANG-UNDANG}

Kitab Undang-Undang Hukum Perdata

Himpunan Peraturan Perundang-Undangan Hak-Hak Atas Tanah

Peraturan Pemerintah No. 10 Tahun 1961 Tentang Pendaftaran Tanah 